\title{
CRIMES AGAINST HUMANITY: THE STRUGGLE FOR GLOBAL JUSTICE
}

\author{
Geoffrey Robertson ( ${ }^{\text {rd }}$ ed, Penguin Books, London 2006) \\ Paperback, pp 627, ISBN 10: 014102463 1, £14.99
}

James Slater ${ }^{*}$

\section{INTRODUCTION}

Crimes Against Humanity: The Struggle for Global Justice ("CAH") is a political, moral, legal and polemical work: as such, it is a comprehensive attempt to address the evils that, in the broadest sense of the concept, constitute crimes against humanity. The book is wide ranging, illuminating and entertaining. It is written in a lively and accessible style. Robertson is not afraid to make his position clear, often with a hard-hitting adjective or caustic aside, which gives the work a refreshing honesty that a more measured or academic approach might avoid. The moral, though not economic or pragmatic, case Robertson makes for the universal, coherent, consistent and systematic protection of human rights across the globe is compelling, and the broad-brush strokes of his argument, and much of its detail, is hard to disagree with. Generally speaking, I am therefore in agreement with Robertson's objectives as set out in CAH, and the methodology he wishes to see used in order to achieve those objectives. There is much to praise in $\mathrm{CAH}$, and it is a valuable contribution to the global promotion and protection of human rights and humanitarian values.

However, it also has flaws. I do not propose a comprehensive examination of these flaws in this review, nor do I propose to summarise critically the content of $\mathrm{CAH}$ in the manner of traditional reviews. Instead I will focus on what I consider to be the most significant flaws. These manifest themselves in two contexts: theoretical and practical. The theoretical flaws flow from a certain conceptual vagueness that lies at the heart of $\mathrm{CAH}$. $\mathrm{CAH}$ is rich in references to legal and moral concepts or concepts that straddle both categories. Thus Robertson refers to justice, international law, torture,

\footnotetext{
* BA (Sussex), LLM (Harvard), PhD (Birmingham), Lecturer in Law, the University of Buckingham. I would like to thank Jonathan Black-Branch for his comments on an earlier draft, and Douglas Guilfoyle for his general input and invaluable assistance with matters of international law. The usual disclaimers apply.
} 
terrorism, atrocities, genocide, human rights, liberty, war crimes and crimes against humanity. But there is no sustained attempt to explain the meaning of these concepts, or the complex relationship between them. This would not necessarily matter, not least because $\mathrm{CAH}$ is meant to be a popular work accessible to non-specialists. But I will argue that it unavoidably matters in two key areas: first, given Robertson's faith in the notion of human rights and its declared central importance to $\mathrm{CAH},{ }^{1}$ it matters because the concept at the heart of the work needs to be defended in some detail to give the book meaning; second, it matters because Robertson's conceptual vagueness leads him into serous error where the European Court of Human Rights case of Sahin v Turkey is concerned, and into unacceptable superficiality where the bombings of Hiroshima and Nagasaki are concerned.

The practical flaws of CAH are two-fold. First, there is a failure by Robertson to engage fully with the practical implications and consequences of his arguments. Robertson is correct to kick up a fuss, but he is not sufficiently concerned with governance and the responsibilities that come with it. He fails to see that lawyers at one level only react, but that his project is not exclusively one of criticism from the outside, but direct and constructive activity from the inside. Second, Robertson fails to place the legal and courtbased approach that he favours into the wider economic, cultural and political framework for promoting humanitarian goals. Throughout $\mathrm{CAH}$, Robertson exhibits an almost blind faith in legal norms and legal mechanisms as the best way of achieving global justice, and in so doing fails to demonstrate awareness of the potential of other norms and mechanisms in achieving his humanitarian agenda.

\section{THE THEORETICAL FLAWS}

\section{Human Rights: Defence and Definition}

Any serious attempt to address the concept of human rights inevitably faces the question of their origin. Crudely put, this question takes the following form: is it universally true that humans are endowed with human rights, or are human rights the creation of certain value systems and cultures, and therefore specific to them? ${ }^{2}$ This question is not merely of academic interest, as it is intertwined with the justification for the universal application and enforcement of human rights norms across cultures, societies and political

\footnotetext{
${ }^{1}$ Robertson declares in the Preface: "But this is not a text book on legal procedures. It aims to tell the human rights story...", see xv.

${ }^{2}$ This is a feature of what is sometimes called the normative debate about rights: for a discussion, see N E Simmonds Central Issues in Jurisprudence (London: Sweet and Maxwell, 2002) Chapter 8 "Rights" generally.
} 
systems. If subscription to human rights principles is one view of life amongst many, then imposing them on cultures, societies etc that reject them is a form of imperialism - an assertion that one culture, or view of life, is better than another. However, if it universally true that all humans possess certain key rights, then the imperialist claim is undermined, and it becomes incumbent on the international community and domestic powers to prevent and punish the crimes that constitute violations of human rights. Or perhaps the best view lies somewhere in between these two extremes, in the sense that possession of human rights may not be an anthropological fact immune to geography, culture and the passage of time, but nevertheless respect for the concept of human rights is useful or correct for the human race at this point in socioeconomic and political development. As Jack Donnelly puts it, the "universality of human rights is a moral claim about the proper way to organise social and political relations in the contemporary world, not an historical or anthropological fact". ${ }^{3}$ Such a view, whilst retaining a strong faith in human rights, remains sensitive to the context in which they are to be applied. I will explore this notion of contextual sensitivity further when I address the practical flaws in CAH.

What is disappointing about $\mathrm{CAH}$ is that, in a major work of 627 pages, in which the concept of human rights is a central concern, there is no serious attempt to engage with the above theoretical debate. Instead, Robertson treats the objective status of human rights as more or less self-evident. ${ }^{4}$ Thus in the Epilogue, he states: "But human rights principles afford individuals such elemental protections against the state that they are sought by intelligent beings everywhere". 5 This statement is followed by a sustained attack on the notion of cultural relativism, in the form of a list of certain barbaric practices followed by rhetorical statements to the effect that cultural relativism cannot excuse such barbarity. ${ }^{6}$ Unfortunately this is not an argument, or at least it is

3 "The Social Construction of International Human Rights" in Tim Dunne and Nicholas J Wheeler (eds) Human Rights in Global Politics (Cambridge: Cambridge University Press, 1999) p 71, p 81. I owe my awareness of this quote to MarieBénédicte Dembour's Who Believes in Human Rights? Reflections on the European Convention (Cambridge: Cambridge University Press, 2006) p 3.

${ }^{4}$ There is a semblance of an argument at $\mathrm{p} 38$, where Robertson states that there is nothing culture dependent or Western in the Universal Declaration of Human Rights because the rights articulated within it have been flouted "by governments of every creed and colour", including those of Western powers (or at least with their connivance). However, this is not a successful argument: the fact that principles are universally flouted lends no support to the notion that those principles are objectively true. Whether principles are respected or flouted, universally or selectively, is neutral on the question of their objective truth.

${ }_{6}^{5} \mathrm{P} 612$.

${ }^{6} \mathrm{Pp} 612-613$. 
not a complete argument: what is needed is some interrogation of the claims to objectivity made by universal rights. There is plenty of material from which to plunder, not least the works of John Rawls, ${ }^{7}$ John Finnis, ${ }^{8}$ Ronald Dworkin ${ }^{9}$ and Robert Nozick. ${ }^{10}$ These thinkers, or at least some of them, should have received sustained attention in CAH. Furthermore, Robertson's claim that human rights principles are subscribed to by intelligent beings everywhere, at least unreservedly, is not true. The negative critiques offered by realist, utilitarian, Marxist, relativist, feminist, and communitarian philosophies are not explored by Robertson. ${ }^{11}$ A more sustained engagement with the various schools of thought that are, at the very least sceptical of, if not in outright opposition to, human rights would have been appropriate. ${ }^{12}$ Robertson may be correct that subscribing to human rights principles is the best way to manage the relationship between the individual or group on the one hand, and the state and other forms of public power on the other, ${ }^{13}$ but this claim should be backed up by some lengthy argument, rather than treating the question as self-evident. Thus the general case for the existence and objective nature of human rights should have been thrashed out in considerably more detail than Robertson offers in CAH. The theoretical heart of the book is missing, a theoretical heart necessary to give CAH its full moral and legal impact.

Theoretical debate about human rights does not end there. There is also the question of the moral and legal architecture of human rights. ${ }^{14}$ The starting point of such a debate is a theoretical definition of a right. And in a book where the notion of a right is central, one would expect such a theoretical definition, even though it need not be overly complex. Yet despite this central concern, there is not a single attempt to define a right theoretically in CAH's

\footnotetext{
${ }^{7}$ See, in particular, A Theory of Justice Revised Edition (Oxford: Oxford University Press, 1999).

${ }^{8}$ See, in particular, Natural Law and Natural Rights (Oxford: Oxford University Press, 1980).

${ }^{9}$ See, for example, Taking Rights Seriously (London: Duckworth, 1977).

${ }^{10}$ See, in particular, Anarchy, State and Utopia (Oxford: Basil Blackwell, 1974).

11 An excellent analysis of the realist, utilitarian, Marxist, relativist and feminist critiques can be found in Dembour, above $n$ 3. For a leading example of communitarian critique, see Michael Sandel Liberalism and the Limits of Justice (Cambridge: Cambridge University Press, 1998).

12 Robertson mentions Bentham and Marx, but their critiques receive only brief attention: see pp 16-18.

13 Robertson does not analyse against whom or what exactly human rights are asserted. There is much talk of the state, but there is also mention of large corporations: see, for example, pp 138 and 611. CAH would be greatly improved by a fairly detailed theoretical exploration of the various forms of power, public or otherwise, against which respect for human rights supplies necessary protection.

14 This is sometimes known as the analytical debate about rights: see above $n 2$.
} 
627 pages. One would expect at the very least mention of Wesley N Hohfeld and the contrast between liberties, residual and negative in nature as Robertson acknowledges at the outset of $\mathrm{CAH}^{15}$ and rights properly socalled, positive in nature and capable of trumping positive law. ${ }^{16}$ This failure to define a right is a flaw in and of itself, but it also has repercussions for the quality of Robertson's analysis more generally. I shall illustrate this with Robertson's discussion of the European Court of Human Rights (the "Court") case of Sahin v Turkey, ${ }^{17}$ where the Court addressed a ban issued by Istanbul University on women wearing the Islamic headscarf on university premises. Before addressing the flaws in Robertson's analysis of this case, however, it is necessary to summarise the content of the decision in some detail.

\section{Sahin v Turkey}

The question for the Court in Sahin $v$ Turkey was whether a ban on women wearing the Islamic headscarf by Istanbul University was compatible with Article 9 of the European Convention for the Protection of Human Rights and Fundamental Freedoms, the Article that enshrines, inter alia, freedom of religion. It is worth quoting Article 9 in full:

1. Everyone has the right to freedom of thought, conscience and religion; this right includes freedom to change his religion or belief and freedom, either alone or in community with others and in public or private, to manifest his religion or belief, in worship, teaching, practice and observance.

2. Freedom to manifest one's religion or beliefs shall be subject only to such limitations as are prescribed by law and are necessary in a democratic society in the interests of public safety, for the protection of public order, health or morals, or for the protection of the rights and freedoms of others.

The Court held that the ban had infringed the applicant's right to manifest her religion, ${ }^{18}$ so attention turned to the legitimate limitations that could be

\footnotetext{
${ }^{15} \mathrm{P} 1$.

${ }^{16}$ Hohfeld's arguments were set out in two famous articles: "Some Fundamental Legal Conceptions as Applied in Judicial Reasoning" (1913) 23 Yale Law Journal 16 and "Fundamental Legal Conceptions as Applied in Judicial Reasoning" (1917) 26 Yale Law Journal 710, reprinted in W W Cooke (ed) Fundamental Legal Conceptions as Applied in Judicial Reasoning (New Haven: Yale University Press, 1964). Hohfeld's ideas have generated an enormous amount of literature. For a discussion, see, inter alia, N E Simonds Central Issues in Jurisprudence, above n 2, pp 275-293.

${ }^{17}$ (2007) 44 EHRR 5.

${ }^{18} \mathrm{Ibid}$, at para [78].
} 


\section{JUSTICE}

placed on that right by Article 9(2). The Court's task was therefore confined to determining whether the reasons given for the interference were relevant and sufficient, and the measures proportionate, to one or more of the legitimate societal aims articulated by Article 9(2). The Court came to the conclusion that the ban was proportionate to those aims, specifically Turkey's avowed intention of promoting pluralism and secularity in a society where religious symbols were gathering a certain amount of negative political significance.

The Court accepted that secularism and pluralism were legitimate social aims that could, in principle, justify restrictions on religious freedom. ${ }^{19}$ In this regard, the Court was conscious of the political effect of wearing the headscarf; it stated:

"...when examining the question of the Islamic headscarf in the Turkish context, there must be borne in mind the impact which wearing such a symbol, which is presented or perceived as a compulsory religious duty, may have on those who choose not to wear it. ... [T] he issues at stake include the protection of the 'rights and freedoms of others' and the 'maintenance of public order' in a country in which the majority of the population, while professing a strong attachment to the rights of women and a secular way of life, adhere to the Islamic faith. Imposing limitations on freedom in this sphere may, therefore, be regarded as meeting a pressing social need by seeking to achieve those two legitimate aims, especially since ... this religious symbol has taken on political significance in Turkey in recent years." 20

This particular political environment was emphasised by the Court:

“... The Court does not lose sight of the fact that there are extremist political movements in Turkey which seek to impose on society as a whole their religious symbols and conception of a society founded on religious precepts..."21

The conclusion of the Court was therefore as follows:

"Having regard to the above background, it is the principle of secularism, as elucidated by the Constitutional Court, which is the paramount consideration underlying the ban on the wearing of

\footnotetext{
${ }^{19} \mathrm{Ibid}$, at paras [104] to [116].

${ }^{20} \mathrm{Ibid}$, at para [115].

${ }^{21}$ Ibid.
} 
religious symbols in universities. In such a context, where the values of pluralism, respect for the rights of others and, in particular, equality before the law of men and women are being taught and applied in practice, it is understandable that the relevant authorities should wish to preserve the secular nature of the institution concerned and so consider it contrary to such values to allow religious attire, including, as in the present case, the Islamic headscarf, to be worn." 22

Once it was established that the University was seeking a legitimate aim within the context of Article 9(2), the next stage of the Court's analysis was whether the ban was proportionate to that aim. ${ }^{23}$ Giving the University a wide margin of appreciation, the Court came to the conclusion that it was proportionate:

"By reason of their direct and continuous contact with the education community, the university authorities are in principle better placed than an international court to evaluate local needs and conditions or the requirements of a particular course. Besides, having found that the regulations pursued a legitimate aim, it is not open to the Court to apply the criterion of proportionality in a way that would make the notion of an institution's 'internal rules' devoid of purpose. Article 9 does not always guarantee the right to behave in a manner governed by a religious belief and does not confer on people who do so the right to disregard rules that have proved to be justified." ${ }^{24}$

Robertson comments on the case as follows:

"Religions and cults are riddled with sexist and superstitious practices: the overdue message of Sahin is that they will receive scant protection if there is a rational justification for denying them public display in places or at times when they are calculated to cause offence or disharmony." 25

This statement wholly misrepresents the decision in a number of ways, which I propose to explore.

Robertson states that the ratio of Sahin is that public displays of religious symbols can be restricted when there is a rational justification for so doing, and the display is calculated to cause offence or disharmony. This is wrong

\footnotetext{
${ }^{22}$ Ibid, at para [116].

${ }^{23}$ Ibid, at para [117].

${ }^{24}$ Ibid, at para [121].

${ }^{25} \mathrm{P} 122$.
} 


\section{CRIMES AGAINST HUMANITY: THE STRUGGLE FOR GLOBAL JUSTICE}

for two reasons. First, rational justification is too wide and too lenient a justificatory concept for denying the freedom: as Article 9(2) and the Court makes clear, the limitation must be proportionate to a legitimate societal end as enunciated in Article 9(2), and this analysis will take place in a particular cultural, historical and political context. The point about context is worth emphasising because no general rule should be extracted from Sahin; as Susan Edwards argues with regard to the decision, Turkey "is an Islamic state de facto; where the population is majority Muslim; and where the endeavour is to ban what Turkey regards as a symbol and representation of a past era which was repressive." ${ }^{26}$ Thus Robertson should be far more circumspect in concluding that Sahin sends out a general message. Secondly, the Court made no mention of a requirement that the display be calculated to cause offence or disharmony: the Court did not require such a guilty mind on behalf the person making the public display of religious affiliation in order to justify the limitation. In fact, as the dissenting judgment of Judge Tulkens (Belgium) pointed out:

"First, the [majority] judgment does not address the applicant's argument--which the Government did not dispute--that she had no intention of calling the principle of secularism, a principle with which she agreed, into doubt. Secondly, there is no evidence to show that the applicant, through her attitude, conduct or acts, contravened that principle." $" 27$

Indeed, as Tulkens went on to observe:

"Freedom to manifest a religion entails everyone being allowed to exercise that right, whether individually or collectively, in public or in private, subject to the dual condition that they do not infringe the rights and freedoms of others and do not prejudice public order.

\footnotetext{
26 "Imagining Islam... of Meaning and Metaphor Symbolising the Jilbab - R (Begum) $v$ Headteacher and Governors of Denbigh High School" (2007) 19 Child and Family Law Quarterly 247, at 268.

27 Above n 17, at para [O-II7]. See also para [101]. See also Nicholas Gibson "Faith in the Courts: Religious Dress and Human Rights" (2007) 66(3) Cambridge Law Journal 657, at 671-672: "Furthermore, no account is taken of, or answer given to, Ms Sahin's evidence that her wearing the headscarf had neither the object or effect of threatening public order or the rights and freedoms of others. As to her object, Ms Sahin stated her decision was one of religious conviction. She had no intention of protesting, pressurising, provoking or proselytising by doing so: she supported secularism. Neither Turkey nor the Court contradict these assertions." Robertson would do well to read Gibson's excellent analysis of the flaws in the Court's judgment.
} 
As regards the first condition, this could have been satisfied if the headscarf the applicant wore as a religious symbol had been ostentatious or aggressive or was used to exert pressure, to provoke a reaction, to proselytise or to spread propaganda and undermined - or was liable to undermine - the convictions of others. However, the Government did not argue that this was the case and there was no evidence before the Court to suggest that Ms Sahin had any such intention. As to the second condition, it has been neither suggested nor demonstrated that there was any disruption in teaching or in everyday life at the university, or any disorderly conduct, as a result of the applicant's wearing the headscarf. Indeed, no disciplinary proceedings were taken against her." 28

Thus Robertson's argument that the ban was justified by the Court, in part or in whole, because the wearing of the headscarf was calculated to cause offence or disharmony misrepresents the facts and rationale upon which the decision was reached.

It is worth noting at this point that Robertson's comment on why the Sahin decision was justified is in serious tension with, if not antinomous, to his approach to the publication, in Denmark, of cartoons featuring the Prophet. He states with regard to the latter event: "But expression cannot be free without the right to shock and offend and certainly not without the right to satirize and ridicule religions of all kinds". ${ }^{29}$ Yet the need to prevent the causing of offence was one of the very reasons, according to Robertson, that the Court was correct to deny the right to wear the Islamic headscarf in Sahin. The existence of a tension between the result in Sahin and a more protective attitude where freedom of expression is concerned was pointed out by Tulkens:

"Unless the level of protection of the right to freedom of religion is reduced to take account of context, the possible effect which wearing the headscarf, which is presented as a symbol, may have on those who do not wear it does not appear to me, in light of the Court's case law, to satisfy the requirement of a pressing social need. Mutatis mutandis, in the sphere of freedom of expression, the Court has never accepted that interference with the exercise of the right to freedom of expression can be justified by the fact that the ideas or views concerned are not shared by everyone and may even offend some people." 30

\footnotetext{
${ }^{28}$ Ibid, at para [O-II8].

${ }^{29} \mathrm{Pp}$ 614-615.

${ }^{30}$ Above n 17, at para [O-II9].
} 


\section{CRIMES AGAINST HUMANITY: THE STRUGGLE FOR GLOBAL JUSTICE}

The attitude of the Court to freedom of expression makes sense: it is logical that in the marketplace of ideas, the frank exchange of views will at some point cause offence, with the result that silencing opinion on such a ground will have an undesirable chilling effect on the quality and integrity of debate, with potentially negative effects on intellectual progress and flourishing. And if freedom of expression is accorded protection on such grounds, it would seem appropriate, at least at first blush, that religion be accorded similar protection. Religion is rich in moral, intellectual, philosophical and spiritual content, and, on occasion, the expression of that content will provoke and offend those who subscribe to secular or other religious viewpoints. Consistency would therefore seem to require that the expression of religious ideas, in its many forms, be accorded similar protection to the expression of ideas generally. I am not claiming that, ultimately, the Sahin decision and the right to publish the Danish cartoons cannot be reconciled, but Robertson makes no attempt to do so. Instead of offering reasoned analysis of why he adopts different approaches to the two freedoms, all that emerges from Robertson's analysis of Sahin and the Danish cartoons is his distaste for religion. ${ }^{31}$

In fact, CAH lacks the conceptual armory to achieve that reconciliation, which may in part explain why the tension escaped Robertson's attention. And this lack of conceptual analysis betrays another problem with Robertson's treatment of Sahin. The notion of value neutrality has a central role in the concept of respect for human rights. The idea is that the State should be neutral on certain substantive political and moral issues, leaving such questions to the individual conscience of its citizens. ${ }^{32}$ Thus the right to freedom of expression exists, in part, because the state should not declare only certain viewpoints acceptable, whilst silencing others, since to discriminate in

\footnotetext{
${ }^{31}$ Another example of Robertson's distaste for religion is his highly misleading, if not false, attack on the Catholic notion of confession: he states that the worst crimes against humanity in Latin America "were committed by devoted members of a Roman Catholic faith that offers forgiveness in exchange for a secret confession", $p$ 327. If I have understood Robertson correctly, he means by this that such crimes can be committed with a happy heart because forgiveness is automatically obtained. If this is Robertson's point, he should know that confession without genuine contrition/repentance, which includes the determination not to sin again, is useless according to Catholic dogma: see para 303 of The Compendium of the Catechism of the Catholic Church (Libreria Editrice Vaticana, 2005). It is also worth noting that this empirical claim is not backed up by a footnote, and, though it may be true, I am certainly curious as to the source of this statistic.

${ }^{32}$ This idea is well captured in the philosophies of John Rawls and Ronald Dworkin, with their notion of State neutrality where competing visions of the good life are concerned: see above ns 7 and 9.
} 
such a way would violate the State's obligation of neutrality. The same rationale underpins the freedoms of association and religion. Rights therefore represent pockets of freedom into which the State cannot venture simply upon the basis of substantive disagreement with how the freedom is exercised. The State must be morally relativist. The problem with Robertson's summary of Sahin, specifically his references to "superstition" and "sexism", is that it justifies the ban in terms of freewheeling moral debate, and this betrays the value neutrality that State respect for human rights entails.

First, in his reference to superstition, Robertson appears to be saying that the Court was supporting rationality in opposition to the irrational; however, it is not the role of the Court to debate the substantive merits of rationality and secularism versus religion. ${ }^{33}$ Entering such a debate, and then upholding the ban in part because the conclusion is reached that Islam is associated with superstitious practices, would betray the State's neutral role where religion is concerned. Secondly, the State cannot silence or restrict religious freedom because it perceives the exercise of that freedom as sexist, as this once more involves a substantive disagreement with the practice itself, and, again, betrays the State obligation of neutrality. The Court itself articulated this requirement for State neutrality:

"The Court has frequently emphasised the State's role as the neutral and impartial organiser of the exercise of various religions, faiths and beliefs, and stated that this role is conducive to public order, religious harmony and tolerance in a democratic society. It also considers that the State's duty of neutrality and impartiality is incompatible with any power on the State's part to assess the legitimacy of religious beliefs or the ways in which those beliefs are expressed...."34

And, in light of this fact, superstition and sexism did not feature in the Court's reasoning for upholding the ban: Turkey was successful by arguing that the values of secularism and plurality, legitimate political objectives that were being pursued in a particular cultural, historical and political context, were sufficient for the case in hand to justify the ban. This is a very particular type of justification that does not engage in debate regarding the merit of Islam, but rather the societal effect of its practice; the Court was concerned with values that are macro and organisational in nature, values aimed at securing a certain kind of political and social framework in which individual liberty can prosper. Neither the University nor the Court was passing

\footnotetext{
${ }^{33}$ After all, many, if not all of the world's religions have a superstitious element; for example, where Christianity is concerned, the Virgin birth, prayer and, for Catholics, transubstantiation, are all superstitious.

${ }^{34}$ Above n 17, at para [107].
} 
comment on whether the practice itself was superstitious or sexist, nor was the Court upholding the ban for such reasons. ${ }^{35}$

Therefore not only is Robertson's failure to engage with any theoretical description of a right a flaw in and of itself, it also seriously hampers his ability to explain, analyse and justify a key case that he quotes with approval. This theoretical failure is not an academic nicety, but actually sets a dangerous practical precedent, because, if Robertson's rationale for the decision were to be followed, the State would possess a content based power to deny freedom of religion, the very power the concept of a human right was meant to deny.

\section{Hiroshima and Nagasaki}

Whilst addressing international humanitarian law in the chapter "War Law", Robertson has the following to say with regard to the use of the nuclear bomb at Hiroshima and Nagasaki:

"The nuclear bomb has been unlawful ever since its drop in 1945 proved massively, indiscriminately and environmentally damaging. That first use on Hiroshima was certainly justifiable on the grounds of military necessity, since nothing less than a demonstration of its annihilatory power would move Emperor Hirohito to even contemplate surrender. It incinerated thousands, but it saved the lives of hundreds of thousands of Allied forces, as well as Japanese soldiers and civilians who would otherwise have been killed. The second bomb on Nagasaki three days later may not strictly have been necessary and should have been dropped elsewhere than on a city, but it does seem to have been the crunch for Japanese capitulation, which came five days afterwards." 36

I do not propose to challenge Robertson's conclusion, but, in light of its importance, to criticise this extract for unnacceptable superficiality. As a preliminary matter, it is not entirely clear what Robertson is arguing here. The extract begins with the claim that the use of the nuclear bomb has been

\footnotetext{
${ }^{35}$ It is worth noting at this point that Robertson's comment about sexism also betrays another misleading and simplistic feature of his approach to the Sahin decision. As Dominic McGoldrick has pointed out, the link between sexism and the wearing of the Islamic veil is far from necessary: the motives for wearing a headscarf are multifaceted, not all of them emblematic of the subordination of women: see the first chapter of Human Rights and Religion: The Islamic Headscarf Debate in Europe (Oxford: Hart Publishing, 2006).

${ }^{36}$ P 219.
} 
unlawful since $1945,{ }^{37}$ but this is followed immediately by the further claim that its use in 1945 was justified, or at least justified where Hiroshima is concerned, with a question mark over Nagasaki. At first blush, it seems as if Robertson might be arguing, in a positivist vein, that the use of the bomb became unlawful after this initial use, but this argument is not made explicitly. Furthermore, CAH is hardly a work that is positivist in nature: indeed Robertson's respect for human rights and humanitarian thinking more generally as a secular moral benchmark for international law emerges clearly throughout the work, so I do not believe that this is the point he is making. Rather, it is more likely that Robertson believes the use of the bomb on Hiroshima and Nagasaki was prima facie unlawful, but that, perhaps exceptionally, it was not all-things-considered unlawful because it saved lives. ${ }^{38}$ This is an important claim that requires lengthy explanation, not least an in-depth analysis of how these two events relate to international humanitarian law and the concepts of crimes against humanity and war crimes, notions of central importance to the "War Law" chapter and CAH as a whole. Unfortunately, that analysis is missing.

Thus, where crimes against humanity are concerned, the definitions given by Article 6(c) of the Charter of the Military Tribunal for the Trial of the Major War Criminals and Article 7 of the Rome Statute of the International Court arguably cover what occurred at Hiroshima and Nagasaki, at least to my amateur eyes. ${ }^{39}$ Furthermore, later in the book, Robertson quotes with approval the following statement from the Tadic judgment as reflecting the rationale for crimes against humanity they:

"so shock the conscience of mankind and warrant intervention by the international community...because they are not isolated, random acts of individuals but rather result from a deliberate attempt to target a civilian population." 40

Once more, one is struck by the potential for this rationale to cover what occurred at Hiroshima and Nagasaki. Yet, despite the fact that there are several uses of the term "crimes against humanity" in the "War Law"

\footnotetext{
${ }^{37}$ Itself a questionable assertion: see $\mathrm{n} 47$ below and text.

38 Furthermore, Robertson offers no evidence for, or analysis of, his claim that dropping the bombs was the only way to persuade Emperor Hirohito to surrender, and that (if I have understood Robertson correctly) this was the main, if not only, motivation for the Americans doing so. It is worth noting that there are dissenting voices on this point: see, for example, B V A Röling and Antonio Cassese The Tokyo Trial and Beyond: Reflections of a Peacemonger (Cambridge: Polity Press, 1994).

39 Robertson himself says that Article 7 is the authoritative definition of crimes against humanity: see $\mathrm{p} 430$.

${ }^{40} \mathrm{P} 400$ (para 653 of the Tadić judgment, 7 May 1997).
} 


\section{CRIMES AGAINST HUMANITY: THE STRUGGLE FOR GLOBAL JUSTICE}

chapter ${ }^{41}$ Robertson does not mention the concept when making the claim that the use of the bomb was justified. One must therefore assume, in light of this silence, that Robertson believes that the use of the bomb on these two occasions escapes the definition. Further support for this assumption is derived from Robertson's claim that the use was justified, since the notion of a crime against humanity would appear to belong to that group of wrongs so heinous as to be incapable of justification. ${ }^{42}$ However, since CAH lacks a sustained conceptual analysis from either a moral and/or legal point of view of what Robertson believes is a crime against humanity, ${ }^{43}$ there is no way of understanding why Robertson thinks these bombings escape the definition. Yet the claim is too important to be ignored.

If the bombings were not unlawful qua crimes against humanity, attention turns to the notion of a war crime, that is to say certain serious violations of international humanitarian law. The deliberate targeting of a civilian objective with a nuclear weapon would seem to be illegal per se under such law, ${ }^{44}$ and other discussion by Robertson in the War Law chapter demonstrates that he thinks so as well. Thus he argues that the use of nuclear weapons against civilians is illegal by quoting the International Court of Justice ('ICJ') Advisory Opinion on the Legality of the Threat or Use of Nuclear Weapons at para $78,{ }^{45}$ where it is stated that States must never make civilians the object of attack, and he pours derision ("weasel words") ${ }^{46}$ on the ICJ's position that it is conceivable that the use of nuclear weaponry could be permissible under international humanitarian law under certain extreme circumstances. ${ }^{47}$ The latter reveals that Robertson believes the use of nuclear weapons should be illegal by definition, that is to say under all circumstances. ${ }^{48}$ One is therefore

${ }^{41} \mathrm{Pp}$ 199, 200, 201, 206 and 212.

${ }^{42}$ Robertson himself describes crimes against humanity as "unforgivable", incapable of amnesty or time limits on prosecution: see xxv of the Introduction.

${ }^{43}$ This is of itself a remarkable omission in light of the book's title.

${ }^{44}$ See Robert Cryer, Håkan Friman, Darryl Robinson and Elizabeth Wilmshurst An Introduction to International Criminal Law and Procedure (Cambridge: Cambridge University Press, 2007) pp 247-253 and 255-256, and Christopher Greenwood "The Law of War (International Humanitarian Law)" in Malcolm D Evans (ed) International Law (Oxford: Oxford University Press, $2^{\text {nd }}$ edn, 2006) p 783, at $\mathrm{p} 800$.

${ }^{45}$ Advisory Opinion of 8 July 1996; see p 224. Robertson incorrectly references the quote he uses as being from para 95 .

${ }^{46} \mathrm{P} 225$.

${ }^{47}$ Advisory Opinion on the Legality of the Threat or Use of Nuclear Weapons, above n 45, paras 95, 96, 97 and 105(2)(E).

${ }^{48}$ Robertson discusses the Advisory Opinion, ibid, at pp 224-226. His contempt for the majority opinion, specifically its refusal to declare a specific ban on the use of nuclear weapons, is clear. Whether that contempt is warranted is itself questionable: see Christopher Greenwood "The Advisory Opinion on Nuclear Weapons and the Contribution of the International Court to International Humanitarian Law" (1997) 
left with a genuine sense of puzzlement as to why he believes their use on Hiroshima, and perhaps Nagasaki, where large civilian populations were deliberately targeted, was justified, and thereby lawful, in light of military necessity. It is not enough simply to declare the use justified: in view of the importance of these two events, Robertson should have devoted considerable time to explaining the theoretical and jurisprudential reasons for his conclusion. These two events are simply too important to be treated so superficially by Robertson.

\section{THE PRACTICAL FLAWS}

Robertson's project is ultimately a practical one. It is about achieving change in a world were injustice is widespread. His preferred method is that of legally and, on occasion, militarily enforced respect for human rights. ${ }^{49} \mathrm{He}$ is therefore concerned with the concrete application of human rights in complex social, cultural, economic and political contexts. This is the question of detail and governance: what does the notion of a human right mean when you disengage it from its abstract moorings and seek to make it engage with, and change, the real world? The question of governance and implementation raises the related question of whether human rights enforcement via legal and military mechanisms is always the best way to achieve the humanitarian goals and respect for human dignity that Robertson rightly holds so dear. I will argue that $\mathrm{CAH}$ exhibits a failure to address either of these two questions in sufficient detail.

Implementation of human rights has multiple dimensions. Above all else, there is the question of finance. The proposals Robertson has in mind, both in terms of manpower and physical infrastructure, are not cheap. However, by the end of CAH, I had no sense of the cost of Robertson's proposals, or where the money is to come from. Robertson can reply that this is not his concern: he is there to highlight the problem. But this is not just a problem of gathering and spending funds that are already available: this is a question of prioritisation in a world where resources are finite. Pragmatic and economic awareness must inform any serious treatment of human rights and the achievement of humanitarian goals. As David Kennedy notes:

"Human rights has elbowed economics aside in our development agencies, which now spend billions once allocated to dams and

International Review of the Red Cross 316. A similar approach to Robertson's can be found in Timothy L H McCormack "A non liquet on Nuclear Weapons - The ICJ Avoids the Application of General Principles of International Humanitarian Law" (1997) International Review of the Red Cross 76.

${ }^{49}$ See, for example, xxv of the Introduction. 
roadways on court reform, judicial training and 'rule of law' injection." 50

Perhaps that is best, but we need to know why economic development, in terms of hospitals, schools, power, transport, medicine etc, should be sacrificed in order to satisfy a human rights agenda. By all means phrase or conceptualise these latter economic needs in terms of rights if you will, but the problem remains as to where to spend the money. CAH is free of any discussion of such questions.

Prioritisation, economic or otherwise, is not only a question of how a human rights agenda is given priority over other forms of humanitarian assistance, but also manifests itself within that agenda itself. This can be illustrated with the death penalty. Robertson is against. ${ }^{51}$ But there is more to this question than opposition to the death penalty. As Kennedy points out:

"...a well-implemented ban on the death penalty, for example, can easily leave the general conditions of incarceration unremarked." 52

This truth is more or less captured by the following observation by a Pegasus Scholarship Placement student in Houston in 2004:

"I was shocked by the prison conditions for death-row inmates. Unless he has a visitor, a death row inmate will spend 23 hours a day alone in a 10 ' by 6' cell with one 3', by 36 "' window. Prisoners are allowed a radio (but no TV) and are permitted only a limited number of books. They spend one hour a day alone in a large indoor room or in a fenced area outdoors. They have no contact with any other inmates, other than shouting through walls or occasionally on the way to the visitor's room. There are no work programmes, education or group recreation opportunities. It seems that the good death-penalty attorneys are so busy representing those at risk of receiving a death sentence or those facing imminent execution, that there is neither the time nor the funding for any litigation about prisoner conditions or prisoner rights." ${ }^{33}$

\footnotetext{
50 "Reassessing International Humanitarianism: The Dark Sides" in Anne Orford (ed) International Law and its Others (Cambridge: Cambridge University Press, 2006) pp 131-135, p 132.

${ }^{51} \mathrm{Pp} 137-156$.

${ }^{52}$ Above n 50, p 134.

${ }^{53}$ Inner Temple Education and Training Handbook 2006/2007, pp 57-58, Natalie Wortley of New Court Chambers.
} 
Now Robertson might respond that this is just a failure to enforce prisoner rights across the board, and to a certain extent that is true. But it is also a warning against the failure to contextualise and to understand the effects of prioritising certain problems at the expense of others. Every failure can be described as a failure to enforce human rights, but the problem remains: which human rights, and when, and how, and how much energy and money, and where should that money be taken from, and where should it be spent first, and at with what sacrifice to other projects? Humanitarians should not ignore these practical questions of implementation. As Kennedy points out, the human rights movement must realise that it is also involved in governance, rather than purely being a critic of it. ${ }^{54}$ In his failure to address these questions, Robertson turns a blind eye to vital steps in the process of seeing his humanitarian priorities converted into concrete results.

It is arguable that such practical concerns do not matter to Robertson's central message, because $\mathrm{CAH}$ is principally concerned with barbaric acts against groups or individuals committed in the name of greed and/or ideology and/or madness that blight human history, in the form of genocide and state sponsored political violence and torture, in times of war or peace. Given the extremes of barbarity of such acts, Robertson can, and does, advocate their prevention and punishment without engaging in overly complex practical and economic debate. I recognise the force of this argument, but feel that $\mathrm{CAH}$ would have been greatly improved if Robertson had fleshed it out. And it is worth noting that $\mathrm{CAH}$ has a broader canvas than such extreme crimes, encompassing freedom of speech, ${ }^{55}$ the rights of women and children, ${ }^{56}$ and also labour, trade and other economic or second generation rights. ${ }^{57}$ These rights are more practically complex: their status and effect is more firmly embedded in the day-to-day management of society and the economy. And this is especially so where second generation rights are concerned. For example, questions of global trade and labour relations require a special kind of expertise, relating to such matters as economics, tax, and the logistics of international trade. Rights in this context, even if one could agree on their abstract articulation, for example that everyone has a right to gainful employment, require careful implementation in concrete situations. Indeed, the abstract support for the right feels like only the first, small step in a

\footnotetext{
54 This is a common theme in the writings of David Kennedy; see, in particular, The Dark Sides of Virtue: Reassessing International Humanitarianism (Princeton and Oxford: Princeton University Press, 2005).

${ }^{55} \mathrm{Pp}$ 116-121.

${ }^{56}$ For women, see, for example, pp 106-107, 520 and 613, for children, see, for example, pp 103-104 and 186.

57 See pp 132-136 (“Peaceful Enjoyment of Property”), pp 174-183 ("Economic and Social Rights"), pp 183-186 ("Labour Rights as Human Rights") and pp 186-191 ("The Duties of Multinational Corporations").
} 
process where implementation and governance are far more important than raw commitment to an abstract idea of what the appropriate rights are in such situations. $\mathrm{CAH}$ would have been enriched if such questions of implementation had been acknowledged in greater depth.

But even the punishment of extreme cruelty is not an open and shut matter. There are still pragmatic and other moral factors that need to be weighed up, such as the argument that the pursuit of a dictator might destabilise a nascent democracy and similar arguments. As Henry J Steiner argues:

"One central concern informs the question of prosecutions. The task after violence has ended may be primarily to rebuild, to lay the foundations for a society more respectful of basic human rights values that extend from control of violence to institutionalisation of political participation, and to achieve some degree of reconciliation that will permit the society to move forward. In such circumstances, prosecutions may hold risks as well as promise, and may even be seen as one among several plausible responses to mass and brutal violations. These choices include truth commissions, lustration, selective or general amnesties that may rest on a popular vote and may involve some quid pro quo on the part of those gaining amnesty, or some combination thereof." 58

Robertson has little or no time for such arguments, ${ }^{59}$ but I feel his dismissal of such concerns is too shallowly considered ${ }^{60}$ Decisions need to be carefully contextualised: a refusal to acknowledge the side-effects of pursuing

\footnotetext{
58 "International Protection of Human Rights" in Malcolm D Evans (ed) International Law above n 44 p 753, at p 766.

${ }^{59}$ Where amnesties are concerned see pp 296-312 (in particular p 311), where truth commissions are concerned see pp 312-323 (in particular p 312, where Robertson states that truth commissions should only be a prelude to trial, not an alternative). See also xi of the Preface, were he describes fears of destabilisation as "risible" in light of the experience of Yugoslavia and Chile post the arrests of Milosevic and Pinochet. See also Neil Boister "Failing to Get to the Heart of the Matter in Sierra Leone?: The Truth Commission is Denied Unrestricted Access to Chief Hinga Norman" (2004) 2 Journal of International Criminal Justice 1100, in which Boister comments on how Robertson, in his capacity as President of the Special Court of Sierra Leone, refused The Truth and Reconciliation Commission of Sierra Leone access to Chief Hinga Norman.

60 I pass no comment on whether such prosecutions are indeed required by international law.
} 
a punitive agenda seems dogmatic and insensitive to the local conditions under which such decisions must be taken and executed. ${ }^{61}$

The question of context betrays another problem with CAH. Robertson seems little concerned with the cultural, historical, economic and political context of the crimes he describes. One can surmise that, as far as Robertson is concerned, that context is irrelevant when considering the evil that has been perpetrated. ${ }^{62}$ And in one sense this is right: nothing can justify or excuse the acts described. But justification and excuse, on the one hand, and explanation, on the other, are different things, and sometimes understanding the often highly complex cultural, historical, economic and political context of these terrible events can reveal other ways to prevent them, or deal with their aftermath. Taking these evil acts entirely out of context and applying a criminal justice solution, whilst perhaps appropriate as part of a more general picture, is nevertheless too limited an approach on its own. Robertson's support for immediate Western legal reform and/or military intervention, a process to be frequently supplemented by prosecutions, as the one and only solution to the humanitarian ills of the world could be seen as arrogant, and on occasion even a distraction from more pressing concerns.

In fact, those with strong faith in criminal justice are always more or less guilty of this myopia, even within the traditional domestic context. I hasten to add that criminal justice always plays a vital role, of general deterrence, and punishment of those who deserve it. But, to illustrate, if you wish to reduce gang related violence in economically deprived urban areas, you cannot talk exclusively in terms of criminal justice: one must also address the causes of such violence and conflict, and this requires a holistic offensive on many different fronts, through education, both at school and through various social groups, and engendering a sense of community and belonging. Indeed, a successful campaign of education and investment in social infrastructure and organisation will arguably reduce crime far more that a heavy-handed criminal justice approach, imposed from above and administered by traditional elites and law enforcement. Robertson, at least in CAH, seems ignorant of these alternative possibilities and methodologies in the

\footnotetext{
${ }^{61}$ See $\mathrm{p} 321$, where Robertson states that the more extreme crimes of Latin America and Africa, in contrast to the less extreme crimes of Eastern Europe, "must...be settled...eventually, in the criminal courts."

${ }^{62}$ For example, in his description of the Tadić Case, he outlines (briefly and exceptionally for $\mathrm{CAH}$ ) the history of the enmity between Serb, on the one hand, and Croat and Muslim, on the other, but the role that history might play in how that enmity could have been prevented from manifesting itself in violence, or healed once the violence had taken place, is not mentioned, see $\mathrm{p} 394$.
} 
international sphere. He conveys, as Kennedy would say, an enchanted view of his humanitarian tools. ${ }^{63}$

These other solutions and prophylactic measures, such as education and dialogue, are embedded in the local culture and history of the participants and acknowledge the stage they have reached in their political and institutional development. By acknowledging cultural context, such measures can achieve results that the immediate application of liberal, rule of law, solutions cannot, and furthermore pave the way for, and complement, the eventual adoption of such solutions. ${ }^{64}$ On occasion, such an approach may entail respecting existing legal and dispute resolution customs that seem antiquated or superstitious to Western eyes, at least in the short to medium term, in order to avoid damaging effects on social cohesion. ${ }^{65}$ And such alternative approaches are particularly potent where social and economic humanitarian projects are concerned. ${ }^{66}$ The result of this is that excessive focus on a human rights approach has potentially harmful effects, as Kennedy points out:

"To the extent emancipatory projects must be expressed in the vocabulary of 'rights' to be heard, good policies that are not framed that way go unattended. This also distorts the way that projects are framed and imagined for international consideration. For example, it is often asserted that the international human rights movement makes

${ }^{63}$ The Dark Sides of Virtue, above n 54, p 119. See also p 130, where this point is made effectively: "The effort to intervene in places like Kosovo or East Timor or Palestine to 'keep the peace' or 'rebuild the society' or 'strengthen the state' or 'provide humanitarian assistance' without affecting the background distribution of power and wealth betrays this bizarre belief in the possibility of an international governance which does not govern (original emphasis)."

${ }^{64}$ As Henry J Steiner convincingly argues in "International Protection of Human Rights", above n 58, at pp 775-779.

${ }^{65}$ In this regard, see Thomas A Kelley III "Exporting Western Law to the Developing World: The Troubling Case of Niger" (2007) 7(3) Global Jurist Article 8. Kelley outlines the societal dangers of immediately displacing Nigerian legal traditions, specifically the use of an oracle called the 'gon' as a means of identifying thieves, with Western legal reform, and instead advocates a gradual transition towards Western legal values for Niger. Kelley's article raises a question mark over Robertson's point, at $\mathrm{p} 38$, that there is nothing hostile in the Universal Declaration of Human Rights to, inter alia, African countries or the culture and aspirations of ethnic groups or tribes.

${ }^{66}$ As Steiner points out with regard to gender discrimination and female genital mutilation/circumcision ('fgm') in "International Protection of Human Rights", above $\mathrm{n}$ 58, at $\mathrm{p}$ 778. Steiner states that where customary practices such as fgm are concerned, "internal dialogue within the community between proponents and opponents of the practice may open a path to change more likely to succeed than a State's effort to prosecute those authorising or performing the ritual surgery." 
an end run around the local institutions and strategies that would often be better - ethically, politically, philosophically, aesthetically. Resources and legitimacy are drawn to the centre from the periphery. A 'universal' idea of what counts as a problem and a solution snuffs out all sorts of promising local political and social initiatives to contest local conditions in other terms." ${ }^{, 67}$

The problem may be that Robertson is concerned with moral wrongs of various kinds but does not see beyond the notion of law and rights as a means of understanding their significance, preventing their occurrence and dealing with their aftermath. Yet the humanitarian project is far wider and more complex than a purely legal and rights based approach can deal with. Robertson, at least in $\mathrm{CAH}$, seems blind to these other possibilities, a more holistic way of looking at the problems that rightly trouble him so much.

\section{CONCLUSION}

In conclusion, I admire CAH: it is a powerful defence of the value of international respect for human rights and the determined pursuit of those persons and organisations who have committed crimes against humanity. But the humanitarian project is complex, especially where matters of implementation are concerned, and is not always advanced by solipsistic vision. My comments on $\mathrm{CAH}$ are therefore meant to trigger further thought on the path to a legitimate end.

67 "The International Human Rights Movement: Part of the Problem?" (2002) 15 Harvard Human Rights Journal 101, at 108. See also The Dark Sides of Virtue, above n 54, p 129. 